\title{
DAMPAK COVID-19 TERHADAP KEGIATAN PEMBELAJARAN ONLINE DI SEBUAH PERGURUAN TINGGI KRISTEN DI INDONESIA
}

\author{
Ericha Windhiyana Pratiwi \\ e-mail: 292017086@student.uksw.edu \\ Universitas Kristen Satya Wacana
}

Jalan Diponegoro No. 52-60, Salatiga, Kec. Sidorejo, Kota Salatiga, Jawa Tengah 50711

\begin{abstract}
Abstrak: COVID-19 merupakan wabah penyakit yang berasal dari Tiongkok yang menyebar dengan cepat ke seluruh dunia. COVID-19 menyebar di Indonesia pada awal Maret 2020. Penyebaran virus ini menyebabkan kerugian untuk banyak negara terutama dalam bidang ekonomi. Dalam bidang pendidikan, COVID-19 juga mengubah model pembelajaran secara drastis; seluruh kegiatan pembelajaran dilakukan secara daring mulai dari tingkat sekolah dasar sampai perguruan tinggi. Penelitian ini merupakan penelitian diskriptif kualitatif yang mendeskripsikan kegiatan pembelajaran daring di Universitas Kristen Satya Wacana setelah ditetapkannya seluruh kegiatan pembelajaran dilaksanakan di rumah dengan mode daring. Subjek terdiri dari 3 mahasiswa dan 2 dosen Universitas Kristen Satya Wacana. Pengumpulan data menggunakan wawancara. Berdasarkan hasil wawancara, kegiatan pembelajaran dengan mode daring di Universitas Kristen Satya Wacana sudah efektif dengan memanfaatkan aplikasi Zoom, Google Classroom, Schoology, dan Edmodo. Kendala dalam pelaksanaan pembelajaran daring yaitu masalah koneksi internet yang kurang mendukung.
\end{abstract}

Kata-kata Kunci: COVID-19, dampak, pembelajaran online

\section{THE IMPACT OF COVID-19 ON ONLINE LEARNING ACTIVITIES OF A CHRISTIAN UNIVERSITY IN INDONESIA}

\begin{abstract}
COVID-19 is an outbreak of disease originating from China which spread rapidly throughout the world. COVID-19 spread in Indonesia in early March 2020. The spread of this virus caused losses to several countries, especially in the field of economic. In the field of education, it also changed the learning model drastically; all learning activities are carried out online starting from elementary school level to university level. This research is a qualitative descriptive study describing online learning activities at a Christian university after the stipulation of all learning activities carried out from home in online mode. Interview was used to collect the data from 3 students and 2 lecturers. Based on the interview results, online learning activities at this university have been effective by utilizing the Zoom, Google Classroom, Schoology, and Edmodo applications. Constraint in implementing online learning mostly is internet connection problems that less supportive.
\end{abstract}

Keywords: COVID-19, impact, online learning

\section{PENDAHULUAN}

Beberapa orang telah mengamati berbagai pandemi yang membahayakan dunia. Pengamatan melalui tahapan yang sangat sulit karena lawan yang akan dihadapi adalah sebuah virus yang tak terlihat, virus itu adalah COVID-19 coronavirus (Nadeem, 2020). Awalnya diamati di Provinsi Wuhan, Tiongkok, sekarang menyebar dengan cepat ke seluruh dunia. Coronavirus merupakan keluarga 
virus yang menyebabkan penyakit mulai dari gejala ringan hingga berat, jenis coronavirus diketahui menyebabkan penyakit yang dapat menimbulkan gejala berat seperti Middle East Respiratory Syndrome (MERS) dan Severe Acute Respiratory Syndrome (SARS) (Kementerian Kesehatan, 2020). World Health Organization memberi nama virus baru tersebut Servere acute respiratory syndrome coronavirus-2 (SARSCoV-2) dan nama penyakitnya sebagai Coronavirus Disease 2019 (COVID-19) (WHO, 2020 dalam (Fakultas Kedokteran Universitas Lampung \& Yuliana, 2020)). Gejala COVID-19 yang paling umum antara lain gejala gangguan pernapasan akut seperti demam, sesak napas, dan batuk kering. Gejala-gejala tersebut muncul ketika tubuh bereaksi melawan virus Corona. (Pane, 2020). Tenaga kesehatan berperan penting dalam memberikan tanggap terhadap wabah COVID-19 dan menjadi ditulang punggung pertahanan suatu negara untuk membatasi atau menanggulangi penyebaran penyakit. COVID-19 (Coronavirus Disease 2019). COVID-19 merupakan sebuah virus yang menyerang pernafasan manusia (Kementerian Kesehatan, 2020). COVID-19 ini masih berhubungan dengan penyebab SARS dan MERS yang sempat muncul pada tahun 2019. Ketiga virus ini diketahui disebarkan oleh hewan dan mampu menjangkit dari satu spesies ke spesies lainya termasuk manusia. Penyebaran coronavirus dari hewan ke manusia sangat jarang, tetapi hal ini yang terjadi pada COVID-19, SARS, dan MERS. Manusia dapat tertular coronavirus melalui kontak langsung dengan hewan yang terjangkit virus ini. Cara penyebarannya disebut transmisi zoonosis. Beberapa hal yang harus dilakukan dalam pencegahan virus ini menurut (Kementerian Dalam Negeri, 2020) yaitu melakukan kebersihan tangan menggunakan hand sanitizer jika tangan tidak terlihat kotor atau cuci tangan dengan sabun jika tangan terlihat kotor, menghindari menyentuh mata, hidung dan mulut, terapkan etika batuk atau bersin dengan menutup hidung dan mulut dengan lengan atas bagian dalam atau tisu, lalu buanglah tisu ke tempat sampah, pakailah masker medis jika memiliki gejala pernapasan dan melakukan kebersihan tangan setelah membuang masker, menjaga jarak (minimal $1 \mathrm{~m}$ ) dari orang yang mengalami gejala gangguan pernapasan.

Diduga COVID-19 pertama kali muncul di Wuhan, Provinsi Hubei, Tiongkok virus ini diduga muncul karena adanya sebuah pasar makanan di Wuhan yang menjual bebagai jenis hewan hidup maupun sudah mati (Nuraini, 2020) Virus ini telah tersebar di seluruh dunia, termasuk Indonesia sejak awal bulan Maret 2020. Pemerintah Indonesia langsung menindak lanjuti kasus tersebut. Salah satu tindakan pemerintah adalah melakukan Social Distancing selama 14 hari untuk meminimalisir penyebaran virus tersebut. Menurut Center for Disease (CDC) dalam (Kosasih, 2020) Social Distancing yaitu menjauhi perkumpulan, menghindari pertemuan massal, dan menjaga jarak antar manusia. Pembatasan sosial/menjaga jarak yang dilakukan untuk mencegah penularan COVID-19 agar tidak menyebar luas di Negara Indonesia. Social Distancing sangat berpengaruh untuk menghambat penyebaran COVID-19. Dampak dari adanya COVID-19 tersebut, menyebabkan perekonomian di Indonesia menjadi merosot, menjatuhkan nilai tukar rupiah, harga barang naik, terutama alat-alat kesehatan. Hal ini juga berdampak pada sistem pendidikan di Indonesia. Hasil keputusan dari menteri pendidikan bahwa seluruh kegiatan pembelajaran baik di sekolah maupun perguruan tinggi dilaksanakan di rumah masing-masing melalui aplikasi yang tersedia. Menteri pendidikan mengeluarkan Surat Edaran Nomor 3 Tahun 2O2O Tentang Pencegahan Corona Virus Disease (COVID-19) Pada Satuan Pendidikan yang menyatakan bahwa meliburkan sekolah dan perguruan tinggi. (Kemdikbud RI, 2020). Hal ini dilakukan untuk memutus mata rantai penyebaran COVID-19, sebagai gantinya kegiatan pembelajaran dilakukan secara online untuk semua jenjang pendidikan. Universitas Kristen Satya Wacana merupakan salah satu perguruan tinggi yang menerapakan kebijakan tersebut. Bentuk perkembangan teknologi informasi yang dapat dimanfaatkan sebagai media pembelajaran adalah menggunakan e-learning (pembelajaran online) (Hartanto, 2016). Pembelajaran online diartikan sebagai suatu jaringan komputer yang saling terkoneksi dengan jaringan komputer lainnya ke seluruh penjuru dunia (Kitao, 1998 dalam (Riyana \& Pd, n.d.)). Aplikasi e-learning ini dapat memfasilitasi aktivitas pelatihan dan pembelajaran serta proses belajar mengajar secara formal maupun informal, selain juga memfasilitasi kegiatan dan komunitas pengguna media elektronik, seperti internet, intranet, CD-ROM, Video, DVD, televisi, HP, PDA, dan lain sebagainya (Darmawan, 2012). Dalam penerapan e-learning (pembelajaran online), dosen dan mahasiswa memiliki perannya masing-masing. Dosen memiliki peran sebagai fasilitator dan pembimbing dalam kegiatan pembelajaran, sedangkan mahasiswa memiliki peran sebagai konstruktor pengetahuan, pembelajar mandiri (independent learners), dan pemecah masalah (problem solvers)(Bintaro \& Kusir dalam Maudiarti, 2018). Di samping itu, istilah 
E-learning (pembelajaran online) meliputi berbagai aplikasi dan proses seperti computer-based learning, webbased learning, virtual classroom, virtual Schoology, virtual Zoom, dan aplikasi lainnya. (Dakwah et al., n.d.) Kegiatan pembelajaran online ini dilakukan untuk mengganti kegiatan pembelajaran secara langsung. Pembelajaran online memiliki beberapa kelemahan yakni penggunaan jaringan internet membutuhkan infrastruktur yang memadai, membutuhkan banyak biaya, komunikasi memalui internet terdapat berbagai kendala/lamban (Haryono, 2003 dalam (Waryanto, 2006)). Meskipun terdapat kendala pembelajaran online dapat dikatakan efektif apabila mahasiswa dapat mencapai tujuan pembelajaran dan mahasiswa aktif dengan adanya interaksi antara dosen dan mahasiswa dalam pembelajaran tersebut dan tidak berpusat kepada dosen saja. Salah satu ciri utama dari pembelajaran mahasiswa yang sangat menonjol adalah adanya kemampuan dan kemauan dalam proses belajar dengan mengarahkan sendiri proses pembelajaran sesuai dengan kebutuhan yang dia inginkan atau disebut juga sebagai self-directed learning atau kerap disingkat sebagai SDL (Merriam, 2011:30) dalam (Wicaksono, 2012). Proses pembelajaran dengan menggunakan SDL dianggap berhasil jika pebelajar telah mampu mengarahkan proses belajarnya tanpa adanya bantuan dari pembelajar (Gibbsons, 2002). E-learning (pembelajaran online) merupakan salah satu pembelajaran yang sudah banyak digunakan di perguruan tinggi saat ini semenjak diterbitkannya sebagaimana diatur dalam Pasal 31 Undang-Undang No. 20 tahun 2003 tentang Sistem Pendidikan Nasional, yaitu mengenai pembelajaran jarak jauh. (Brito, 2003) Universitas Kristen Satya Wacana telah menyediakan pembelajaran online sejak dulu, yang dirancang oleh BTSI (Biro Teknologi dan Sistem Informasi) yang dinamakan f-learning. Beberapa dosen menggunakan pembelajaran mealaui f-learning ini, sedangkan beberapa dosen lainnya menggunakan pembelajaran online mengguakan aplikasi seperti Schoology, Google Classroom, Edmodo, dan aplikasi lainnya. Pelaksanaan pembelajaran online untuk mengantisipasi apabila dosen tidak dapat tatap muka dengan mahasiswa dan untuk menghadapi kendala mendadak seperti pandemi COVID-19 yang menggemparkan seluruh dunia sehingga menyebabkan seluruh aktivitas manusia dibatasi. Beberapa model online learning menurut (Haugey \& Anderson, 1998) dalam buku Networked Learning: The Pedagogy of The Internet menjelaskan terdapat tiga model model e-learning, yaitu (1) Web Course, yaitu perkuliahan yang dilakukan melaui web merupakan pembelajaran online secara utuh bahwa terdapat pola komunikasi antara mahasiswa dengan dosen yang didominasi sistem jarak jauh melalui web/ internet dan tidak terjadi pertemuan tatap muka. Seluruh bahan ajar, penugasan, konsultasi, ujian, dan kegiatan pembelajaran lainnya disampaikan melalui internet, (2) Web Centric Course, yaitu memadukan pembelajaran jarak jauh dan tatap muka secara online pada pekuliahan model ini materi sebagian disediakan di web dan sebagian melalui tatap muka, dan fungsinya saling melengkapi, (3) Web Enhanced Course yaitu perkuliahan yang ditingkatkan melalui pemanfaatan web/internet. Pembelajaran tersebut terjadi timbal balik antara dosen dan mahasiswa serta pembelajaran berpusat pada web/internet".

Adapun kelebihan dalam melakukan pembelajaran online, salah satunya adalah meningkatkan kadar interaksi antara mahasiswa dengan dosen/guru, pembelajaran dapat dilakukan dimana dan kapan saja (time and place flexibility), Menjangkau peserta didik (mahasiswa) dalam cakupan yang luas (potential to reach a global audience), dan mempermudah penyempurnaan dan penyimpanan materi pembelajaran (easy updating of content as well as archivable capabilities) (Siahaan, 2002 dalam (Waryanto, 2006)). Model pembelajaran ini memanfaatkan teknologi terutama dalam membantu dosen dan mahasiswa terutama pada pengelolaan kegiatan pembelajaran (Basori, 2017). Dengan teknologi informasi ini dapat berperan sebagai media yang menyediakan antara mahasiswa dan dosen, sumber belajar dan sarana untuk meng-efesiensikan evaluasi pembelajaran (Sriwihajriyah et al., 2012).

Keuntungan penggunaan pembelajaran online adalah pembelajaran bersifat mandiri dan interaktivitas yang tinggi, mampu meningkatkan tingkat ingatan, memberikan lebih banyak pengalaman belajar, dengan teks, audio, video dan animasi yang semuanya digunakan untuk menyampaikan informasi, dan juga memberikan kemudahan menyampaikan, memperbarui isi, mengunduh, para siswa juga bisa mengirim email kepada siswa lain, mengirim komentar pada forum diskusi, memakai ruang chat, hingga link videoconference untuk berkomunikasi langsung (Arnesti \& Hamid, 2015). Kebijakan yang dibuat oleh pimpinan Universitas Kristen Satya Wacana ini dilakukan agar mengurangi grafik penyebaran COVID-19 yang semakin hari semakin bertambah angka kematian maupun yang tertular. Berdasarkan hal tersebut peneliti ingin meneliti bagaimana dampak COVID-19 terhadap pembelajaran online di Universitas Kristen Satya Wacana. 


\section{METODE PENELITIAN}

Jenis penelitian ini adalah deskriptif kualitatif. Penelitian kualitatif adalah penelitian yang berlandaskan filsafat post positivisme yang digunakan untuk meneliti kondisi objek yang alamiah dimana peneliti sebagai instrumen kunci dan hasil penelitiannya le-bih menekankan makna dari pada generalisasi (Sugiyono, 2009). Penelitian deskriptif merupakan penelitian yang dilakukan untuk mendeskripsikan suatu variabel, baik satu variabel atau lebih (independen) tanpa membuat perbandingan, atau menghubungkan variabel satu dengan variabel lainnya (Sugiyono, 2009) Di dalam penelitian ini, data yang dikumpulkan berupa kalimat dan penjabaran jawaban dari subjek yang dilakukan dengan wawancara. Pengambilan subjek menggunakan metode snowball throwing. Subjek terdiri dari 3 mahasiswa dan 2 dosen di Universitas Kristen Satya Wacana. Instrumen penelitian terdiri dari peneliti sebagai instrumen utama dengan instrumen bantu wawancara. Data dalam penelitian ini berupa wawancara online melalui WhatsApp yang merupakan jawaban dari subjek merupakan deskripsi dari pengaruh COVID-19 terhadap perguruan tinggi Universitas Kristen Satya Wacana.

Berikut pedoman wawancara yang digunakan:

Tabel 1.

Pedoman Wawancara

\begin{tabular}{ll}
\hline \multicolumn{1}{c}{ Subjek } & \multicolumn{1}{c}{ Pertanyan } \\
\hline Dosen dan 1. & $\begin{array}{l}\text { Bagaimana pelaksanaan } \\
\text { kegiatan pembelajaran di } \\
\text { Universitas Kristen Satya } \\
\text { Wacana setelah terjadinya } \\
\text { pandemik COVID-19? } \\
\text { 2. }\end{array}$ \\
& $\begin{array}{l}\text { Aplikasi apa yang digunakan } \\
\text { dosen untuk melaksanakan } \\
\text { kegiatan pembelajaran online? } \\
\text { Bagaimana pelaksanaan } \\
\text { pembelajaran online dengan } \\
\text { menggunakan a plikasi } \\
\text { tersebut? } \\
\text { Bagaimana hasil dari } \\
\text { pembelajaran online tersebut? }\end{array}$ \\
\hline
\end{tabular}

Adapun wawancara yang dilakukan kepada dosen 1 yang sudah menyiapkan kelas virtual sejak awal semester kegiatan pembelajaran pembelajaran online berjalan lancar, pembelajaran masih bisa dilakukan secara tatap muka melalui aplikasi Zoom Meeting dosen bisa melihat mahasiswa yang memperhatikan maupun tidak memperhatikan, diskusi dapat dilakukan secara fleksibel dan menyenangkan, Meskipun terdapat kendala pada mahasiswa yang keadaan lingkungan tidak memadai sehingga susah signal dan membuat lemot. Sedangkan perkulian online dosen 2 kegiatan pembelajaran dilaksanakan melalui Google Classrom dan Zoom. Google Clasroom digunakan untuk membagikan informasi dan materi dan Zoom digunakan untuk mengabsen siswa dan berdiskusi terkait materi yang telah dibagikan. Kegiatan perkuliahan melalui Zoom menyenangkan dan dilakukan secara fleksibel. Kendala yang dialami dalam pembelajarn online yaitu masalah koneksi internet yang tidak stabil, akan tetapi pembelajaran tetap berjalan. Dosen membuat strategi waktu perkuliahan dilaksanakan pagi hari karena koneksi internet lancar. Pembelajaran online yang dilakukan dosen 2 sudah efektif. Sedangkan wawancara kepada mahasisiwa 1 dalam pelaksanaan kegiatan pembelajaran online sudah efektif karena kegiatan pembelajaran berjalan dengan baik meskipun koneksi internet kurang mendukung sehingga terdapat beberapa informasi yang kurang jelas, akan tetapi apabila informasi kurang jelas siswa diminta untuk bertanya dan dosen akan menjelaskan kembali materi yang disampaikan. Mahasiswa 2 dan mahasiswa 3 tidak jauh berbeda pendapatnya dengan mahasiswa 1 .

\section{HASIL DAN PEMBAHASAN}

Hasil penelitian menunjukkan bahwa pembelajaran yang dilaksanakan di UKSW semenjak adanya virus COVID-19 yaitu menggunakan sistem pembelajaran online. Menurut mahasiswa 1 sistem pembelajaran online sudah efektif. Kegiatan pembelajaran online berjalan dengan baik dan menyenangkan meskipun terdapat suatu kendala dalam menggunakan aplikasi Zoom yaitu situasi dan kondisi keadaan lingkungan rumah atau jaringan (signal) maka dapat menghambat mahasiswa yang koneksi internetnya lamban, akan tetapi apabila terjadi informasi yang kurang jelas dosen akan mengulang penjelasannya hingga mahasiswa memahami materi yang diberikan dosen. Aplikasi yang digunakan untuk mata kuliah yang diambilnya menggunakan Schoology, Google Classroom, dan Zoom.

Berikut cuplikan wawancara 1:

$P$ : Bagaimana pelaksanaan kegiatan pembelajaran di Universitas Kristen Satya Wacana setelah terjadinya pandemik COVID-19?

M1 : Pembelajaran dilakukan secara online.

$\mathrm{P} \quad$ : Aplikasi apa yang digunakan dosen untuk melaksanakan kegiatan pembelajaran online?

M1 : Aplikasi yang digunakan dosen saya yaitu Schoology, Google Classroom dan Zoom. 
P : Bagaimana pelaksanaan pembelajaran online dengan menggunakan aplikasi tersebut?

M1 : Pelaksanaan berjalan dengan baik, namun ada kendala dalam penggunaan aplikasi Zoom yaitu masalah koneksi internet yang lamban dan menghabiskan kuota dengan cepat. Sehingga terdapat beberapa materi yang kurang jelas, tetapi dosen selalu mengulang apabila koneksi kurang baik.

Sedangkan menurut mahasiswa 2 pembelajaran online dilakukan untuk menyelesaikan perkuliahan yang belum selesai, namun pembelajaran online belum cukup efektif karena penyampaian materi dan pemahaman beberapa mahasiswa kurang memperdalam sehingga mahasiswa sulit memahami maksud akan tugas. Karena kendala koneksi internet. Aplikasi yang digunakan tidak berbeda dengan mahasiswa 1.

Berikut cuplikan wawancara 2:

$\mathrm{P}$ : Bagaimana pelaksanaan kegiatan pembelajaran di Universitas Kristen Satya Wacana setelah terjadinya pandemik COVID-19?

M2 : Pembelajaran online sebagai jalur untuk menyambung pembelajaran yang belum usai.

P : Aplikasi apa yang digunakan dosen untuk melaksanakan kegiatan pembelajaran online?

M2 : Menggunakan Zoom, Schoology, dan Google Classroom.

$\mathrm{P}$ : Bagaimana pelaksanaan pembelajaran online dengan menggunakan aplikasi tersebut?

M2 : Pembelajaran cukup efektif, tetapi ada kendala ketika menggunakan aplikasi Zoom yaitu koneksi internet yang berakibat penyampaian materi kurang jelas, memakan banyak kuota dan dosen menjelaskan kembali apabila mahasiswa kurang jelas. Jam perkuliahan dilakukan secara fleksibel.

Pendapat mahasiswa 3 tidak jauh berbeda dengan mahasiswa 1 yaitu pembelajaran online yang dilakukan di Universitas Kristen Satya Wacana sudah efektif karena banyak dosen yang memberikan sistem pembelajaran online yang berbeda-beda seperti Zoom, Schoology, Google Classroom dan berbagai jenis aplikasi lainnya, kendala yang disampaikan mahasiswa 3 sependapat dengan mahasiswa 1 yaitu masalah signal.
Berikut cuplikan wawancara 3:

$\mathrm{P}$ : Bagaimana pelaksanaan kegiatan pembelajaran di Universitas Kristen Satya Wacana setelah terjadinya pandemik COVID-19?

M3 : Pembelajaran dilakukan secara online oleh dosen.

P : Aplikasi apa yang digunakan dosen untuk melaksanakan kegiatan pembelajaran online?

M3 : Dosen menggunakan aplikasi Zoom, Schoology, dan Google Classroom.

$\mathrm{P}$ : Bagaimana pelaksanaan pembelajaran online dengan menggunakan aplikasi tersebut?

M3 : Pembelajaran online sudah efektif karena dosen memberikan pembelajaran online yang berbeda-beda. Tetapi ketika menggunakan aplikasi Zoom terdapat suatu kendala yaitu koneksi internet yang membutuhkan signal yang kuat apabila keadaan lingkungan mahasiswa kurang mendukung akan lemot, untuk Schoology dan Google Classroom tidak ada masalah.

Dari segi pandang dosen 1 berpendapat bahwa pembelajaran ini telah beliau siapkan sejak awal perkuliahan untuk pelaksanaan perkuliahan yang diajarkannya. Jadi tidak masalah apabila kampus memberlakukan sistem pembelajaran online. Aplikasi yang digunakan dalam kegiatan perkuliahan yaitu Edmodo dan Zoom. Beliau tidak sama sekali mengalami kendala dalam kegiatan perkuliahan online, namun letak kendala terdapat pada mahasiswanya yaitu masalah signal dan kendala kuota.

Berikut cuplikan wawancara dosen 1 Mata Kuliah Manajemen Pendidikan:

$\mathrm{P}$ : Bagaimana pelaksanaan kegiatan pembelajaran di Universitas Kristen Satya Wacana setelah terjadinya pandemik COVID-19?

D1 : Tetap berjalan melanjutkan kelas virtual yang saya buat.

P : Aplikasi apa yang digunakan dosen untuk melaksanakan kegiatan pembelajaran online?

D1 : Aplikasi yang saya gunakan untuk kelas saya yaitu Zoom dan Edmodo. Untuk Edmodo saya gunakan untuk share materi berbentuk file untuk Zoom saya gunakan untuk berdiskusi.

$\mathrm{P} \quad$ : Bagaimana pelaksanaan pembelajaran online dengan menggunakan aplikasi tersebut?

D1 : Menurut saya pembelajaran sudah efektif, tidak ada kendala tetapi malah kendala 
terdapat pada mahasiswa yaitu signal dan kuota internet. Karena saat menggunakan aplikasi Zoom membutuhkan banyak kuota dan jaringan internet yang kuat.

$\mathrm{P}$ : Bagaimana hasil dari pembelajaran online tersebut?

D1 : Hasil belum terlihat karena belum sampai tahap penilaian akhir semester.

Sedangkan menurut dosen 2 kegiatan perkuliahan setalah menyebarnya COVID-19 kegiatan perkuliahan di Universitas Kristen Satya Wacana menggunakan sistem pembelajaran online, dalam kegiatan pembelajaran online ini selalu dipantau oleh BMK atau lembaga yang mengkoordinir pelaksanaan pembelajaran di kampus. Aplikasi yang beliau gunakan yaitu Google Classroom dan Zoom. Aplikasi Zoom cenderung membuat siswa lebih fokus pada dosen dan dosen dapat melihat satu persatu wajah mahasiswa dibandingkan dengan pembelajaran langsung. Pembelajaran lewat Zoom yang diampu beliau menyenangkan. Menurut beliau pembelajaran online tersebut sudah efektif, tetapi juga memiliki kendala yaitu masalah koneksi internet. Pembelajaran ini belum bisa dikatakan berhasil karena belum sampai pada tahap pemberian nilai kepada mahasiswa.

Berikut cuplikan wawancara dosen 2 dengan Mata Kuliah Penulisan Karya Ilmiah

$\mathrm{P}$ : Bagaimana pelaksanaan kegiatan pembelajaran di Universitas Kristen Satya Wacana setelah terjadinya pandemik COVID-19?

D2 : Masih tetap berjalan dengan pembelajaran online, tetapi terus dipantau oleh BMK

$\mathrm{P} \quad$ : Aplikasi apa yang digunakan dosen untuk melaksanakan kegiatan pembelajaran online?

D2 : Aplikasi saya gunakan Google Classroom dan Zoom.

$\mathrm{P}$ : Bagaimana pelaksanaan pembelajaran online dengan menggunakan aplikasi tersebut?

D2 : Untuk Google Classroom saya gunakan untuk membagikan informasi-informasi terkait mata kuliah saya dan untuk Zoom saya gunakan untuk diskusi dan mengabsen mahasiswa. Pelaksanaan pembelajaran lewat Zoom lebih menyenangkan karena saya dapat melihat wajah-wajah mahasiswa saya dan dapat tahu mahasiswa yang memperhatikan dan tidak memperhatikan tetapi kendala yang dialami apabila diskusi yaitu koneksi internet yang kurang mendukung untuk mengatasi ini saya memilih waktu yang tepat ketika koneksi internet lancar.
P : Bagaimana hasil dari pembelajaran online tersebut?

D2 : Untuk hasil saya belum bisa mengatakan karena kegiatan pembelajaran belum selesai sehingga belum melihat hasil dari mahasiswa.

Hasil penelitian dapat disimpulkan bahwa dampak COVID-19 terhadap kegiatan pembelajaran online di Universitas Kristen Satya Wacana oleh dosen 1 dalam Mata Kuliah Manajemen Pendidikan sudah efektif dengan menggunakan aplikasi Edmodo dan Zoom yang sudah beliau siapkan sejak awal, pembelajaran dapat berjalan sebagai penyambung untuk menyelesaikan kegiatan pembelajaran yang belum selesai. Kendala yang dialami terdapat pada mahasiswa yaitu masalah koneksi internet dan kuota mahasiswa. Sedangkan pembelajaran online dosen 2 dalam Mata Kuliah Penulisan Karya Ilmiah pembelajaran berjalan dengan lancar, perkuliahan dilaksanakan secara fleksibel. Aplikasi yang digunakan yaitu Google Classroom sebagai tempat untuk mengirimkan materi dan Zoom digunakan untuk mengabsen dan diskusi mahasiswa. Perkuliahan online ini dilakukan untuk menyelesaikan kegiatan pembelajaran yang belum terselesaikan. Pembelajaran melalui Zoom yang diampu dosen 2 menyenangkan karena mahasiswa menjadi aktif dan dosen 2 dapat melihat wajah mahasiswa satu persatu sehingga pembelajaran dapat dikatakan sudah efektif, meskipun terjadi kendala koneksi internet pembelajaran tetap berjalan dengan pembelajaran dilaksanakan secara fleksibel.

Hasil wawancara mahasiswa dapat disimpulkan pembelajaran online sebagai salah satu jalur penghubung pembelajaran yang belum usai menjadi salah satu solusi di Universitas Kristen Satya Wacana sebagai pengganti kegiatan pembelajaran tatap muka, meskipun terdapat kendala, pembelajaran masih tetap berjalan dengan baik. Aplikasi yang digunakan untuk pembelajaran online yaitu Zoom, Google Classroom, dan Schoology.

\section{PENUTUP}

\section{Simpulan}

Simpulan dari penelitian ini adalah COVID-19 sebuah virus menyerang sistem pernafasan manusia. Gejala-gejala COVID-19 antara lain gejala pernapasan akut seperti deman, sesak napas, dan batuk kering. Pemerintah menindaklanjuti untuk memutus penyebaran COVID-19 dilakukan sistem Social Distancing yang merupakan pembatasan 
sosial/menjaga jarak dengan orang lain, menjauhi perkumpulan, dan menghindari pertemuan massal, sebaiknya untuk tetap di rumah saja. Disamping Social Distancing juga harus tetap menjaga kebersihan dengan mencuci tangan setelah melakukan kegiatan, menghindari menyentuh mata, hidung, dan mulut, ketika bersin menutup mulut dan hidung, buanglah tisu ketempat sampah, dan gunakan masker setiap keluar rumah. Setelah tersebarnya COVID-19 mengakibatkan perekonomian menjadi merosot dan kegiatan pendidikan diliburkan sementara, sebagai pengganti kegiatan pembelajaran tatap muka di alihkan dalam kegiatan pembelajaran secara online. Pembelajaran online merupakan pembelajaran yang dilaksanakan dengan menggunakan koneksi internet sebagai penghubung terjalinnya komunikasi antara pendidik dan peserta didik tanpa adanya kontak fisik. Pembelajaran online memiliki beberapa kelemahan yaitu penggunaan jaringan internet membutuhkan infrastruktur yang memadai, membutuhkan banyak biaya, komunikasi melalui internet terdapat berbagai kendala/lamban. Disamping itu juga terdapat kelebihan yang meliputi kadar interaksi antara mahasiswa dengan dosen, pembelajaran dapat dilakukan dimana dan kapan saja (time and place flexibility), Menjangkau peserta didik (mahasiswa) dalam cakupan yang luas (potential to reach a global audience), dan mempermudah penyempurnaan dan penyimpanan materi pembelajaran (easy updating of content as well as archivable capabilities). Setelah keluarnya surat edaran dari Kemendikbud RI No 3 Tahun 2020 tentang pencegahan Corona Virus Disesase (COVID-19) pada satuan pendidikan yang menyatakan bahwa kegiatan belajar mengajar diliburkan sementara. Pemerintah Jawa Tengah langsung menanggapi surat tersebut dengan mengeluarkan surat edaran nomor 420/0005956 tentang pencegahan penyebaran Corona Virus Disease (COVID-19) pada satuan pendidikan Jawa Tengah. Gubernur Jawa Tengah memutuskan seluruh sekolah diliburkan dan kegiatan pembelajaran dilakukan secara online. Hal ini menyebabkan kegiatan pembelajaran di perguruan tinggi Universitas Kristen Satya Wacana dilakukan secara online. Kegiatan perkuliahan online tersebut dilaksanakan melalui laman yang sudah disediakan kampus yang dirancang oleh BTSI (Biro Teknologi dan Sistem Informasi) yang dinamakan f-learning. F-learning ini sudah digunakan oleh beberapa dosen, beberapa dosen lainnya memanfaatkan aplikasi yang tersedia di Play Store/App Store yang sering digunakan yaitu Google Classroom, Schoology, Zoom, dan Edmodo. Dari hasil wawancara pembelajaran online di Universitas Kristen Satya
Wacana berjalan dengan baik dan efektif karena dapat menyelesaikan perkuliahan yang belum terselesaikan dengan kendala secara umum yaitu masalah signal dan kuota mahasiswa. Media yang digunakan dalam pembelajaran online di perguruan tinggi Universitas Kristen Satya Wacana yaitu menggunakan aplikasi Zoom, Schoology, Edmodo, dan Google Classroom.

\section{Saran}

Dari hasil wawancara penelitian ini, maka terdapat saran untuk memperbaiki pembelajaran online ini untuk semester selanjutnya apabila pembelajaran sepenuhnya dilakukan secara online dalam menghadapi pandemi COVID-19 di Universitas Kristen Satya Wacana dengan memberikan subsidi kuota internet untuk mahasiswa agar kegiatan pembelajaran berjalan dengan lancar dan mahasiswa tidak mengeluh masalah pembelian kuota yang menjadi terasa berat di kantong.

\section{DAFTAR PUSTAKA}

Arnesti, N., \& Hamid, A. (2015). Penggunaan Media Pembelajaran Online - Offline Dan Komunikasi Interpersonal Terhadap Hasil Belajar Bahasa Inggris. Jurnal Teknologi Informasi \& Komunikasi Dalam Pendidikan, 2(1). https:/ / doi.org/10.24114/ jtikp.v2i1.3284.

Basori, B. (2017). Efektifitas Komunikasi Pembelajaran Online Dengan Menggunakan Media E-Learning Pada Perkuliahan Body Otomotif. Jurnal Ilmiah Pendidikan Teknik Dan Kejuruan, 7(2), 39-45. https://doi.org/10.20961/jiptek.v7i2.12722.

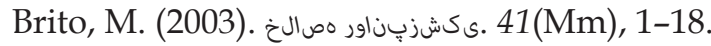

Dakwah, S. F., Uin, K., \& Fatah, R. (n.d.). SISTEM MANAJEMEN PEMBELAJARAN ONLINE, MELALUI. 60-76.

Fakultas Kedokteran Universitas Lampung, \& Yuliana *). (2020). Corona virus diseases (COVID-19); Sebuah tinjauan literatur. Wellness and Healthy Magazine, 2(1), 187-192.

Gibbsons, M. (2002). The Self-Directed Learning Handbook. John Wiley and Sons.

Hartanto, W. (2016). Penggunaan E-Learning sebagai Media Pembelajaran. Jurnal Pendidikan Ekonomi, 10(1), 1-18.

Kemdikbud RI. (2020). Edaran Tentang Pencegahan Wabah COVID-19 di Lingkungan Satuan Pendidikan Seluruh Indonesia.

Kementerian Dalam Negeri. (2020). Pedoman Umum Menghadapi Pandemi COVID-19 Bagi Pemerintah Daerah. 1-206. https://doi.org/10.1017/ CBO9781107415324.004. 
Kementerian Kesehatan. (2020). Pedoman Pencegahan dan Pengendalian Coronavirus Disease (COVID-19). 3, 1-116.

Maudiarti, Santi. (2018). Penerapan E-Learning di Perguruan Tinggi. Perspektif Ilmu Pendidikan, 32 (1), 53-68.

Nadeem, S. (2020). Coronavirus COVID-19: Available Free Literature Provided By Various Companies, Journals and Organizations Around the Literature Provided By Various Companies, Journals and Organizations Around the World. March. https:// doi.org/10.5281/zenodo.3722904.

Riyana, C., \& Pd, M. (n.d.). Konsep Pembelajaran Online. Sriwihajriyah, N. ;, Ruskan, E. L. ;, \& Ibrahim, A.
(2012). Sistem pembelajaran dengan e-learning untuk persiapan ujian nasional pada SMA Pusri Palembang. Jurnal Sistem Informasi (JSI), 4(1), 450-449.

Waryanto, N. H. (2006). On-line Learning Sebagai Salah Satu Inovasi Pembelajaran. In Pythagoras (Vol. 2, Issue 1, 10-23). http:/ / staff.uny.ac.id/ sites/default/files/132304807/Online Learning sebagai Salah Satu Inovasi Pembelajaran.pdf.

Wicaksono, S. R. (2012). Kajian Pembelajaran Online Berbasis Wiki Di Lingkup Perguruan Tinggi. Journal of Education and Learning (EduLearn), 6(1), 51. https://doi.org/10.11591/edulearn. v6i1.190. 